\title{
Religious Pluralism and Sustainable Environment: The Nigerian Situation
}

\author{
Ugwu, C. O Tagbo \\ Department of Religion and Cultural Studies \\ University of Nigeria, Nsukka- Nigeria
}

\author{
Doi:10.5901/mjss.2013.v4n16p55
}

\begin{abstract}
This paper focuses on the challenges of environmental sustainability in the light of the pluralistic religious nature of Nigeria. Using a critical qualitative analytical method, it was found that respective practices of the major religions in Nigeria-African traditional religion, Christianity and Islam, have been contributing to the deterioration of the natural environment in the country. Hence, the researcher, among other things, recommends a collectively unified religious effort towards the conservation and sustenance of the country's environment.
\end{abstract}

Keywords: religious pluralism, sustainable environment, religious conflicts, diversity, stewardship.

\section{Introduction}

The ecological habitat is facing a lot of challenges threatening its extinction largely because of human activities. Some of these challenges include the indiscriminate melting of the ice caps, the rise in sea level, extreme weather conditions, loss of rare species of plants and animals and so on. Arguably, the natural environment is vital and falls within the ambient of religion. Hence, an Iranian-American philosopher Nasr wrote that "the environmental crisis is fundamentally a crisis of values, and that religion being the primary source of values in any culture, are thus implicated in the decisions humans make regarding the environment" (www.en.m.wikipedia.org). Suffice it to say that no religion thrives luxuriantly in an inauspicious environment. First and foremost if a particular environment made up of material and immaterial, human and spiritual forms is hostile or antagonistic, no religion that has man at its epicenter of concern will survive there. The environment therefore becomes a conducio sine qua non for the survivability and sustainability of the practice of religion.

Given this backdrop and considering our environment Nigeria, our task in this paper will be to highlight the environmental challenges in the country and to create a niche for the major religions in the country in the fight for a sustainable environment. More specifically, this paper will take a voyage through the clarifications of concepts, environmental challenges and culpability of religions in Nigeria, The major religions and doctrinal positions on environmental stewardship, religious pluralism and sustainable environment in Nigeria, and then recommendations and conclusion. The above will form the fulcrum on which the investigation or this academic exercise will revolve. To these we turn in the above listed order.

\section{Conceptual Clarifications}

Conceptual clarifications will be necessary for a better understanding:

Religion: Tylor (1866) defined "religion as the belief in the spirit beings". Whereas for Idowu (1973:58), religion is "the belief in the existence of a supernatural ruling power, the creator and controller of the universe, who has given to man a spiritual nature which continues to exist after the death of the body". It can be seen as the belief in the existence of the Supernatural Being that controls man, his affairs and his 
environment, and to which he is accountable.

Sustainable Environment: An environment, for Akinbode (2002) is the totality of places and surroundings, in which we live, work and interact with other people in our cultural, religious, political and socio-economic activities for self-fulfilment and advancement of our communities, societies or nations. It is within this environment that both natural and man-made things are found. Environment can also be seen as the air, land and water where people, animals and plants live. Sustainable environment, therefore, refers to the environment whose natural features like the air, land, water, human, animals and plants are in a pristine condition for a long period of time. To this end, sustainable environment implies the maintenance of the factors and practices that enhance the quality of the environment on a long term basis.

\section{Environmental challenges and Culpability of religions in Nigeria}

Over the years, the problem of climate change has been on the front burner of International discourse. Several global conferences have been held and some are ongoing. The ultimate goal of these conferences has been to salvage the earth from the imminent ecological disaster. This is because the earth has suffered an age-long environmental injustice resulting from anthropogenic (human) activities. For instance, the Nigerian ecological environment has been suffering from some environmental injustice like air and water pollution, deforestation, soil degradation, indiscriminate dumping of refuse, poor drainage and sewage system, bush burning, oil spills, gas flaring and the like. And at the receiving end, are the people who suffer a lot of ecological disasters like respiratory problem, desert encroachment, loss of biodiversities, poor agricultural productivity, floods and attendant loss of lives, property and mass displacement, diseases, increased poverty and destitution. However, the most notable of these ecological disasters in the country is flood. Nigerians are still frightened by the memory of the year 2012 floods which ruinously swept through the country. Recounting the damages of these floods, Akpoborie (2012) wrote;

From Cross River, Akwa Ibom, Rivers, Bayelsa, Delta, Anambra, Imo, through Edo to Niger, Benue, Taraba, Jigawa, Plateau and Kogi states came accounts of woe, death and destruction of homes, public buildings, roads, bridges, public utilities, crops, livestock and farms. Hundreds of thousands of hectares of farms have been swept away (about 400,000 hectares in Jigawa State alone) while millions of people who have lost everything to the floods are being accommodated in temporary camps scattered all over the country.

These are the accumulated consequences of the human industrial, commercial and domestic activities in the country. However, particularly, the religions in the country have a share of the blame for the state of the Nigerian ecological environment. First and foremost is the evidence of intolerance among these religions which have given rise to crises and wars that have repeatedly affected the natural environment of the country. These religious wars have lead to the destruction of lives- human and animal. While some undiscovered dead bodies of human and animal arising from these conflicts often putrefy and cause health problems, some plants and trees are often destroyed during these conflicts. This is not to mention the tons of green house gases that are often emitted from the burning of houses, as well as fossil fuels by thousands of people who relocate as a result of these wars. In fact, the environmental impacts of these conflicts are enormous. Similarly, the religion orchestrated terrorist attacks by the Boko Haram sects have not meant well for the environment as each bomb explosion releases some tons of sulphur dioxide, ash and dust into the atmosphere, which contribute to climate change.

Furthermore, the buildings of churches and mosques as well as religion-based schools by these religions have also impacted on the environment. For instance, cases abound in which some churches buy thousands of hectares of land initially covered with vegetations and wild lives for the establishment of church based universities and high schools like the Covenant University, Caritas University and so on. Likewise, their Muslim counterparts are culpable as they also acquire lands for purposes like for the erection of 
mosques and other religious buildings across the country. All these lead to the loss of vegetations and wild lives. Besides, the illegal siting of churches and mosques on water canals do not help the environment as such acts often contribute to flooding, as a result of poor drainage systems. Again, Nigerian Christians contribute to the depletion of the environment through their evangelical missions like the organization of crusades and other such programmes that warrant the transportation of members from one part of the country to another. According to Fuglestvet et al (2007) "transportation creates air pollution, including nitrous oxides and particulates, and is a significant contributor to global warming through the emission of carbon dioxide." Similarly, religious pilgrimages or journeys have also had great environmental impact on the country and beyond. It has been estimated that globally, religious adherents embark on 150 million journeys every year" (www.arcworld.org). For instance, every year about 2 million Muslims converge at Mecca the holiest place in Islam for the Haji (BBC News, $6^{\text {th }}$ Jan. 2006). Two holy cities, 'Makkah' and 'Madinah' hosted about 2.4 million pilgrims during the 2007 edition of Haji. And about 95, 000 pilgrims from Nigeria participated in the 2008 edition (Garba 2008). Likewise, in 2009, the number of Christian pilgrims from Nigeria to Israel was estimated to be 20,000 (Sydelle 2009). The implication is that since transportation (land, water or air) contributes to global warming through the emission of carbon dioxide; it means that the more people embark on journeys, the more the climate degenerates. All these and more are some of the ways the practice of religion has adversely affected the natural environment in Nigeria. The African traditional religious practitioners are not left out in this environmental assessment. Several traditional activities like burning of bush before the proper cultivation of farmlands, deforestation, and rearing of livestock which according to environmental scientists, release methane and other dangerous greenhouse gases into the atmosphere are adversely contributing to climate change. These have contributed in no small measure to the insecurity of the environment. Expectedly, one would want to know how these are religious. But, it should be quickly noted that the daily activities of an African and Nigerian in particular, is part of his religion." Ugwu and Ugwueye (2004:49) have observed that "the African world is suffused with religion". Africans carry their religion into their routine activities, "from what they eat or cannot eat) the way they farm, do everyday chores, hunt, make tools and clothes" (www.exploningafrica.msu).

However, it would be misleading to conclude that these religions are entirely destructive and environmentally unfriendly. As a matter of fact, these religions have auspicious views on the conservation of the natural environment, which shall be discussed in the succeeding sub-heading.

\title{
4. Major Religions in Nigeria and the Natural Environment
}

The major religions in Nigeria include the following- African Traditional Religion, Christianity and Islam. We shall be looking at each of these religions from the viewpoint of their doctrinal positions on the conservation of the natural environment.

\section{African Traditional Religion}

This is an indigenous religion of Africans and whose origin is traced to time immemorial. Awolalu(1976) defines this religion as

\begin{abstract}
...the indigenous religion of the Africans. It is the religion that has been handed down from generation to generation by the forebears of the present generation of Africans. It is not a fossil religion (a thing of the past) but a religion that Africans today have made theirs by living it and practicing it.(p.275)
\end{abstract}

It is a religion founded on the African soil and its natural environment, interwoven with the culture of the people. The environmental friendly nature of the African traditional religion is based on the fact that the religion finds expression in nature. This qualifies it to be categorized under the umbrella of "nature religion" which according to Beyer(1998) is a "useful analytical abstraction referring to any religious belief or practice 
in which devotees consider nature to be the embodiment of divinity, sacredness, transcendence, spiritual power, or whatever cognate term one wishes to use". It is the consistent observation of the African traditional religion that made Madu(1996:74) conclude that "traditional religions of Africa are natural religions since our belief systems are gained through human insight of the universe". For instance, the indigenous religion of Africans involves the belief in natural spirits that inhabit natural elements like the skies which control the rain that is important to the raising of crops and animals. It is also believed that spirits live and control rivers, lakes, oceans; inhabit rocks, mountains, caves, grooves and trees. Hence, the preservation and conservation of these ecological features are important to African traditional religion. Totemism also has a place in African Traditional religion. Totems refer to special animals or symbolic objects that "serve as emblem of a group of people such as a family, clan, group, lineage or tribe reminding them of their ancestry (or mythic past) (Merriam-Webster online Dictionary ). In the same vein, Mbiti (1969:105) has observed that "a totem is the visible symbol of unity, of kinship, of belongingness, of togetherness and common affinity". Hence, these totemic animals like snakes, agama lizard e.t.c are often surrounded with taboos as owners do not kill or eat them except on rare national events. Other areas of inextricable relationship between African traditional religion and the natural environment are expressed in the traditional practices of building shrines with the aid of rocks, caves and trees in the forests; the several rituals that commemorate special events like planting and harvesting seasons, as well as the belief in "the Earth goddess (called "Ala" among the Igbo people of Eastern Nigeria) for whom it is believed to be the god of fertility and justice". (Ugwu and Ugwueye; 2004:40). All these and more, go to establish a fact that the notion of environmental care and conservation is an intrinsic value of African Traditional Religion. However, there were and still traces of environmental injustices perpetrated by African traditional religion. These include the crude years of human sacrifices and twin killing practices, deforestation, bush burning etc.

\section{Christianity}

Christian religion is based on the life and teachings of Jesus Christ. It is a missionary religion and believed to have entered Nigeria through the southeast (Onitsha) in 1857 from Sierra Leone through Christian missionaries. (Okonkwo and Nzeh; 2009). It is a monotheistic religion with the Bible as the major source of doctrine.

Nevertheless, in some quarters, Christianity has been seriously indicted for the current environmental crisis and climate change. Lynn White seems to be at the fore front of this position, as he argued in a 1966 lecture before the American Academy of Arts and Sciences, that "western Christianity having de-sacralized and instrumentalized nature to human ends, bears a substantial burden of guilt for the contemporary environmental crises (www.en.wikipedia.org). This position is further given breathe by the biblical verse which gave man dominion over the earth (Gen 1:28). According to Ituma (2009);

One of the human positions which have made the earth very hard for man to establish a harmonious and peaceful existence is the idea that the earth must be exploited and manipulated for the benefits of man. As a result of this position human idea about the earth is how to remove everything without some control or replenishment.

Indeed, there is a misconception about this biblical stance of "Man's dominion over the earth". This does not necessarily give man the right to pillage the earth; instead it gives an understanding that man is the superior of all creatures, and as such should be in charge and take the responsibility of caring for the earth. Furthermore, Christianity cannot bear the "burden of guilt" alone, as has been established in previous pages that other religions are also culpable.

There are many verses in the Bible that encourage environmental care and stewardship. Apart from the aforementioned verse which gave man dominion over the earth (Gen 1:28), Leviticus 25:23-24 reminded man thus: "the land is mine and you are but aliens and my tenants. Throughout the country that you hold as possession, you must provide for the redemption of the land". Also in Psalm 24:2, it is stated that, "the earth 
is the LORD's and the fullness thereof, the world, and they that dwell therein". The earth expresses God's power, majesty, glory, and wisdom and should be accorded due deference. It is the Christian belief that the earth is beautifully made out of the creative mind of God for the inhabitation of man. According to Song (1998:454) "the divine declaration that creation is "very good" (Gen 1:31) establishes the natural world as the proper context for human fulfilment. Mankind's vocation is to be found in respect for nature and the stewardship of its order". However, instead of this deference, gross disrespect, disregard and utter disdain characterize man's attitude towards nature". Hence, the earth is currently in shambles and its beauty eroding away"'. No wonder Pope Benedict XVI lamented that;

Can we remain indifferent before the problems associated with such realities as climate change, desertification, the deterioration and loss of biodiversity, the increase of natural catastrophes and the deforestation of equatorial and tropical regions? Can we disregard the growing phenomenon of environmental refugees, people who are forced by the degradation of their natural habitat to forsake it and often their possessions as well in order to face the dangers and uncertainties of forced displacement? Can we remain impassive in the face of actual and potential conflict involving access to natural resource? (www.vatican.va/holyfather)

From the foregoing, it is evident that our Christian leaders are neither oblivious of this threatening situation on our environment, nor are they aloof.

\section{Islam}

This is one of the major religions in Nigeria. Islamic religion in early eleventh century arrived northern Nigeria and in sixteenth century, it was well established in major cities of the northern states, from where it spread to the countryside and toward the middle belt uplands (Okonkwo and Nzeh; 2009). It teaches the belief in one God (Allah) and Prophet Muhammad (Allah's prophet and founder) with the Quran and the Hadith as major sources of doctrine.

As has been seen in other religious views on the subject matter of environmental care and stewardship, the Islamic view also emphasizes that humans are stewards and guardians of nature. In the opening paragraph of the Muslim Declaration on Nature in Assisi, Italy, Naseef (1986) wrote to say that;

The essence of Islamic teaching is that the entire universe is Allah's creation. Allah makes the waters flow upon the earth, upholds the heavens, makes the rain fall and keeps the boundaries between day and night. The whole of the rich and wonderful universe belongs to Allah, its Maker. It is Allah who created the plants and the animals in their pairs and gave them the means to multiply

Nature has been given to humans for safekeeping, not to ruthlessly exploit and pillage it as has been the case. According to the Alliance of Religions and Conservation (ARC) "Allah is unity, and his unity is reflected in the unity of humanity and nature." (www.arcworld.org). Indeed, it is the responsibility of humans to strive for harmony in relations with the natural world. McDermott (2011) has noted that the concept "Trusteeship" is the fulcrum on which the Islamic idea of the "unity of humanity and nature" is based. Hence, Naseef (1986) again wrote to say that;

Unity, trusteeship and accountability, that is tawhid, khalifah and akhirah, the three central concepts of Islam, are also the pillars of the environmental ethics of Islam. they constitute the basic values taught by the Qur'an. it is these values which led Muhammad, the Prophet of Islam, to say: 'Whosoever plants a tree and diligently looks after it until it matures and bears fruit is rewarded', and 'If a Muslim plants a tree or sows a field, and men and beats and birds eat from it, all of it is a charity on his part', and again, 'The world is green and beautiful, and Allah has appointed you as His stewards over it. 
These highlight the important place nature occupies in Islamic religion. But, one would not stop wandering why the earth's environment has been subjected to an age-long injustice, given the fact that virtually all religions claim to have the idea of "creation care" at heart?

\section{Religious Pluralism and Sustainable Environment in Nigeria}

It is no more news that Nigeria is a pluralistic society in both religion and culture. Pluralism, according to Laguda (2013) "suggests divergent views". Nickles (1976:157) defined a pluralistic society as "one in which there co-exist more than one religion and philosophy and there are some degree of recognition by all the parties concerned..." This is typical of the Nigerian situation in which the three major religions- Christianity, Islam and African Traditional Religion share largely incompatible views and theology. However, it is this religious pluralistic nature of the country, that has, in the words of Ekwue (2006:41) that "lead to persistent prejudice, suspicion, distrust, intolerance, aggression and destruction of lives and property." Indeed, the rift and rancor that has arisen from the inter-religious relations in Nigeria, calls for a swift attention. The country has lost a great fortune to religious conflicts and wars that often have Muslims and Christians as key players. According to Salawu (2010:345)

...with the notable historical cases of religious conflicts like the Maitatsine religious disturbances in parts of Kano and Maiduguri in the early 1980s; Jimeta-Yola religious disturbances in 1984; Zango Kataf crises in Kaduna state in $1992 \ldots$ it means that since a long time ago, many parts of Nigeria have become theaters of wars.

As has been noted earlier, these conflicts have not only affected the socio-economic and political life of the nation, but has significantly affected the environment as well. There is no doubt that disagreements and conflicts are common features of a pluralistic society by the virtue of their divergent views. In any case, everything depends on the understanding of the parties involved. A good orientation of members on the intrinsic value in diversity often enhances good understanding for peaceful coexistence. Madu (1996: 86) has argued that the saying "it takes two to tango" or that "no man is an island" should be the guiding principle in a pluralistic society. Perhaps, this is because very little or nothing can be achieved 'alone'. Powel (1985) has observed that;

A human loner is a contradiction in terms, the existence of a human in isolation from others, is like a tree without water. No new growth can occur and the life that does exist begins to whither and will slowly die. For us to be is to be with another or others. The quality of our existence is grounded on our relationship.

This underscores the great underlining value in diversity and pluralism. A society irrespective of its pluralistic nature and diversity has a unifying goal which can only be attained collectively and supportively. Yet, there is hardly a perfectly complete homogenous society anywhere, without some diversities in interest, value orientations and philosophy. Hence, Madu (1996:86) argued, "as there are different men, so also are different ideas and when those different ideas are shared by all, then we may have higher insights".

The pluralistic religious nature of Nigeria, therefore, should not be a weakness, but strength. Though there are obvious theological incompatibilities, the unity in the Supernatural Reality that is the pivot of all religion, should always create a platform for unity. More importantly, since the issue of environmental or creation, care and stewardship cuts across all the religions, there should be a unified religious action towards the achievement of a sustainable environment in Nigeria. The earth and its natural environment belongs to Chukwu, God and Allah, which are different names for one Being, believed to be the creator of the whole universe. Hence, the paradox of "the One" and "the Many". (Madu 1996:38). The earth and its natural environment was beautifully created for the inhabitation of man, whose reciprocal duty is to care for the earth which is his abode. To this end, Nche (2012:76) wrote thus; 
An aesthetic look at the waters and its inhabitants, the flowers, the plants and the trees; as well as a topographic analysis of the lands, well structured hills, mountains and fearful valleys; and a critical study of the processes that bring rain; as well as the various climatic seasons would show how beautiful, the earth is. The earth was made for the inhabitation and sustenance of man and which in turn, should be sustained and preserved by man.

These religions-African traditional religion, Christianity and Islam, should therefore rise above the mutual suspicion and intolerance, to a collective fight against environmental degeneration and injustice in Nigeria.

\section{Recommendations}

Following from the above, these religions should:

- Henceforth, become ecologically conscious to check and curtail some religious practices that contribute to the degeneration of the environment in the country.

- Sensitize their respective adherents and the Nigerian general public on the need to conserve the natural environment; while educating them on some eco-friendly actions such as proper disposal of refuse, planting of trees, proper situation of buildings to avoid water canals and so on.

- Establish an Interfaith Organisation for the primary purpose of promoting environmental stewardship and conservation in Nigeria and should be fashioned after the international organization- the Alliance of Religions and Conservation (ARC).

- Serve as a check on the government, from the standpoint of the proposed interfaith Organization, to ensure good environmental governance by encouraging eco-friendly policies.

- Encourage birth and population control among their respective adherents in the country. The country's population currently stands at 167 million and it has been projected that in 2050, it shall increase to 303.6 million due to the current rate of growth. The implication is that the more the population grows, the more conflict for limited resources, the more poverty grows and the more pressure on the natural environment.

\section{Conclusion}

In conclusion, the ecological habitat belongs to everyone, irrespective of one's religious affiliations- whether an indigenous religious practitioner, a Christian or a Muslim. Moreover, as was earlier noted, no religion with man as its epicenter will survive in an inauspicious environment. And it is conspicuously evident that no one is spared in any ecological disaster as was the case in the cataclysmic year 2012 deluge in Nigeria. All hands therefore, should be on deck in order to achieve a sustainable friendly environment in Nigeria through the sphere and realm of religion.

\section{References}

Akinbode, A. (2002) Introductory Environmental Resource Management. Ibadan: Daybis Limited, pp. 1-2.

Akpoborie, T. (2012). Special Report: 2012: A Year of Raging Floods (www.westafricaninsight.org). Assessed on $26^{\text {th }}$ August, 2013.

BBC News, $6^{\text {th }}$ January, 2006. (www.bbc/new.html) Assessed on $20^{\text {th }}$ August 2013.

Ekwue, B.C (2006) Utilization of Religion for Unity in Nigeria. In M.T, Yahya (ed) Issues in the Practice of Religion in Nigeria. Nigeria Association for the Study of Religion.

Fuglestvet et al (2007) Climate Forcing from the Transport Sectors. Center for International Climate and Environment Research. 
Garba, Kabir Alabi (2008) Islamic Pilgrimage: Hajj. Guardian Newspaper Ltd. Sunday, January 13.

Idowu, (1954) African Traditional Religion. London: SCM Press Ltd.

Indigenous African Religions (www.exploringafrica.matirx.msu.edu). Assessed on 17th August, 2013.

Ituma, E.A. (2009) The Social Context of Incarnation Theology. Nigerian Journal of Humanities and Social Sciences Vol. 3, pp. 5-15.

Laguda, D.O. (2013) Religion and Politics in a Pluralistic Society: The Nigerian Experience (www.politicsandreligionjournal.com) Assessed on 20th August, 2013.

McDermott, M. (2011) Humans are Trustees of Allah's Creation: Islam and the Environment (www.freehugger.com) Assessed on $27^{\text {th }}$ August 2013.

Message of His Holiness Pope Benedict XVI for the Celebration of the World Day of Peace (www.vatican.va/holyfather2010). Accessed on 27th August 2013.

Naseef, A.O. (1986) The Muslim Declaration on Nature - Assisi 1986 (www.greenfaith.org) Assessed on 27th August 2013.

Nche, G.C. (2012) Challenges of Climate Change: The Role of Christian Religious Leaders. Journal of Educational and Social Research (Vol. 2) No. 10, pp 73-80.

Okonwo, E.E. and Nzeh, C.A. (2009) Faith-based Activities and their Tourism Potentials in Nigeria (www.academicexcellencesociety.com) Assessed on 26 th August 2013.

Powel, J. et al (1985) Will the Real Me Pleasure Stand up? U.S.A.

Salawu, B (2010) Ethno-Religious Conflicts in Nigeria: Causal Analysis and Proposals for New Management Strategies. European Journal of Social Sciences (vol.13) No.3.

Song, R.J. (1999) Theology of Nature: New Dictionary of Theology. Leicester: Inter-Varsity Press.

Sydelle, S (2009) Nigerian Curiosity: Pilgrims to Israel. www.nigeriancuriosity.com. Assessed on $20^{\text {th }}$ August 2013.

Tylor, E.B. (1891) Primitive Culture. London.

Ugwu, C.O.T and Ugwueye, L. E. (2004). African Traditional Religion: A Prolegomenon.Lagos: Merit International Publications. 